\title{
Jakość życia pacjentek z rozpoznaniem nowotworu piersi
}

Quality of life in patients diagnosed with breast cancer

\section{Streszczenie}

Rak piersi stanowi drugą co do częstości przyczynę zgonów spowodowanych przez nowotwory złośliwe u kobiet. Rak piersi we wczesnych stadiach rozwoju nie wywołuje objawów, jednak w okresie zaawansowanej choroby powoduje liczne objawy fizyczne, ale także zaburza funkcjonowanie w sferze psychologicznej, społecznej, rodzinnej, seksualnej i duchowej. Jakość życia związana ze stanem zdrowia stanowi najważniejszy aspekt życia każdego człowieka. Kobiety z rozpoznaniem raka piersi cechuje obniżona jakość życia, w porównaniu z populacją zdrową. Ocena jakości życia kobiet z rakiem piersi, jako chorobą dającą odległe skutki, jest niezwykle istotna, również dla powodzenia leczenia przeciwnowotworowego i objawowego. Wśród czynników warunkujących jakość życia wymieniane są 4 grupy: zmienne socjodemograficzne, zmienne kliniczne, czynniki psychosocjalne i przekonania zdrowotne. Ocena jakości życia pozwala dobrać korzystne dla pacjentki leczenie, a poziom jakości życia posiada także znaczenie rokownicze. Interwencje mające na celu poprawę jakości życia mogą wydłużyć czas przeżycia kobiet z rakiem piersi.

Palliat Med Pract 2018; 12, 3: 143-150

Słowa kluczowe: jakość życia, leczenie, objawy, rak piersi

\section{Abstract}

Breast cancer is the second most common cause of death caused by malignant tumors in women. Initially, breast cancer does not give symptoms, but then it manifests itself not only with unpleasant physical and mental symptoms, but also disturbs functioning in the social, family or sexual sphere. The quality of life associated with the state of health is the most important aspect of every human life. Unfortunately, women with breast cancer still have a reduced quality of life in relation to the healthy population. Assessing the quality of life of women with breast cancer as a disease with long-term effects is extremely important also for the success of the therapy. Among the determinants of quality of life 4 groups are mentioned: sociodemographic variables, clinical variables, psychosocial factors and health convictions. The assessment of quality of life allows us to choose a treatment beneficial for the patient and also has prognostic importance. Interventions to improve the quality of life can increase the survival of women with breast cancer.

Key words: quality of life, treatment, symptoms, breast cancer

Adres do korespondencji: Natalia Świątoniowska

Zakład Pielęgniarstwa Internistycznego, Uniwersytet Medyczny we Wrocławiu

ul. K. Bartla 5, 51-618 Wrocław

tel.: 792916193

e-mail: natalia.swiat@o2.pl 


\section{Wstęp}

Rak piersi jest drugą — po raku płuca — przyczyną zgonów spowodowanych przez nowotwory złośliwe u kobiet [1], rozpoznawany jest niemal wyłącznie u kobiet, u mężczyzn rak piersi stanowi $1 \%$ wszystkich lokalizacji nowotworów. W Polsce rak piersi rozpoznawany jest u ponad 16,5 tys. chorych rocznie [2]. Rak piersi występuje częściej w krajach wysoko rozwiniętych i zamożnych. W Polsce częstość zachorowań na raka piersi jest o $35 \%$ niższa, w porównaniu ze średnią dla krajów Unii Europejskiej [1]. Jednak współczynnik zapadalności wzrósł z 200 do 340 na 100 tysięcy kobiet rocznie. Wzrost ryzyka zachorowania na raka piersi obserwuje się szczególnie w grupie wiekowej 45-69 lat, natomiast połowa zachorowań dotyczy grupy kobiet pomiędzy 50. a 69. rokiem życia. Współczynnik zgonów z powodu raka piersi wzrasta po 45. roku życia, natomiast w przedziale wiekowym 50-79 lat pozostaje niezmienny [3].

Hipoteza o związku ryzyka zachorowania na raka piersi z ciążą wskazuje, że im w młodszym wieku kobieta zajdzie $w$ pierwszą donoszoną ciążę, tym mniejsze jest ryzyko zachorowania na raka piersi. Epidemia raka piersi jest spowodowana zmianą modelu prokreacji. W procesie inicjacji i promocji raka piersi istotną rolę odgrywają estrogeny $i$ ich metabolity. Inne czynniki ryzyka (doustne środki antykoncepcyjne, zastępcza terapia hormonalna w okresie menopauzy, promieniowanie jonizujące, alkohol) odgrywają mniejszą rolę. Wyniki leczenia raka piersi zależą w znacznym stopniu od wczesnego rozpoznania; możliwości prewencji pierwotnej są ograniczone [4].

Ocena jakości życia (QoL, quality of life) kobiet z rakiem piersi, jako chorobą powodującą odległe skutki, jest niezwykle istotna. Choroba nowotworowa manifestuje się nie tylko objawami fizycznymi i psychicznymi, ale także zaburza funkcjonowanie w sferze społecznej, rodzinnej czy seksualnej. Według badania Montazeri, jeżeli kobieta zachoruje na raka piersi, wszyscy członkowie rodziny mogą zachorować na jakąś chorobę [5]. Ocena jakości życia pozwala dobrać korzystne dla pacjentki leczenie, a poziom jakości życia posiada znaczenie rokownicze. Interwencje mające na celu poprawę jakości życia mogą wydłużyć czas przeżycia kobiet z rozpoznaniem raka piersi.

\section{Leczenie i objawy niepożądane}

Leczenie chorych na raka piersi jest najczęściej postępowaniem skojarzonym: metody miejscowe (chirurgia i radioterapia) oraz leczenie systemowe (chemioterapia, hormonoterapia i metody biologiczne). Wybór sposobu leczenia zależy od wielu czynników prognostycznych i predykcyjnych. Z zastosowaną metodą leczenia związane są określone działania niepożądane, które mogą istotnie wpływać na poziom jakości życia chorych na nowotwory piersi (tab. 1).

\section{Objawy choroby}

Objawy raka piersi zależą od stopnia zaawansowania, we wczesnych etapach często przebiega bezobjawowo, w zaawansowanej fazie zależą od rozległości zmian miejscowych i lokalizacji ognisk przerzutowych [8]. Objawy dotyczą sfery fizycznej, psychicznej i socjalnej (tab. 2).

\section{Jakość życia — definicje}

Jakość życia związana ze stanem zdrowia stanowi najważniejszy aspekt życia każdego człowieka. Według De Walden Gałuszko jakość życia można określić jako obraz własnego położenia życiowego dokonywany przez człowieka w określonym przedziale czasu. Określa on poziom własnego życia w zakresie poszczególnych kategorii odnoszących się do podstawowych cech życia [12]. Biorąc pod uwagę dwa wymiary, które są wzajemnie powiązane ze sobą - indywidualny i społeczny, określa na ile życie powinno być szczęśliwe i zadowalające, a dokładne spojrzenie na szerokie spektrum czynników subiektywnych i obiektywnych determinujących jakość życia uwidoczniło, że określają one charakter życia zarówno poszczególnych osób, jak i całych grup społecznych.

Światowa Organizacja Zdrowia (WHO, World Health Organization) określa, że jakość życia jest indywidualnym sposobem postrzegania przez jednostkę jej życiowej pozycji zarówno w aspekcie kulturowym, jak i systemie wartości, w jakim żyje oraz w odniesieniu do standardów wyznaczonych uwarunkowaniami środowiskowymi, zadań i oczekiwań. Określa zdrowie w szerokim znaczeniu jako pojawienie się dobrego samopoczucia psychicznego, fizycznego i społecznego, a nie brak choroby [13].

Jakość życia jest to stan samopoczucia, na który wpływ mają czynniki psychiczne, fizyczne, emocjonalne oraz funkcjonalne. Jakość życia jest powiązana ze zdrowiem, poczuciem własnej wartości, udanym życiem rodzinnym, umiejętnością radzenia sobie $w$ trudnych sytuacjach, dobrymi kontaktami społecznymi i poczuciem bezpieczeństwa [14].

Jakość życia to pojęcie wielowymiarowe, interdyscyplinarne, łączące wiele istotnych dziedzin życia. W ujęciu socjologicznym jest stopniem zaspokojenia potrzeb ważnych dla człowieka, w aspekcie psychologicznym oznacza dobrostan psychiczny [15]. Jakość życia to zagadnienie wieloznaczne i dlatego definicja 
Tabela 1. Skutki uboczne leczenia raka piersi [6-7]

\begin{tabular}{|c|c|}
\hline Metoda leczenia & Objawy niepożądane \\
\hline Chirurgia & $\begin{array}{l}\text { Wzrost ryzyka infekcji, sztywność mięśni szyi i pleców, ograniczenie ruchomości w stawie ra- } \\
\text { miennym po stronie operowanej, zaburzenie czucia na skórze w okolicy operowanej, obrzęk } \\
\text { ramienia/przedramienia po stronie operowanej, ból }\end{array}$ \\
\hline Hormonoterapia & $\begin{array}{l}\text { Uczucie gorąca, zaczerwienienie skóry twarzy, przerost błony śluzowej macicy, wzrost ryzyka } \\
\text { zachorowania na raka trzonu macicy, zwiększenie masy ciała, powikłania zakrzepowo-zatorowe, } \\
\text { zaburzenia miesiączkowania, menopauza, retencja płynów, uszkodzenie wątroby, zmniejszenie } \\
\text { libido, wzmożona potliwość, impotencja, ginekomastia, zmniejszenie odporności, choroba } \\
\text { wrzodowa żołądka i dwunastnicy, nadciśnienie tętnicze, nietolerancja glukozy, osteoporoza, } \\
\text { miopatia, hipokaliemia, krwawienia z dróg rodnych, upławy, torbiele jajników, zaćma, zaburze- } \\
\text { nia pamięci, kojarzenia i snu, sztywność poranna stawów, bóle kostno-stawowe, złamania kości }\end{array}$ \\
\hline Radioterapia & $\begin{array}{l}\text { Odczyny popromienne miejscowe (rumień, świąd, łuszczenie skóry, zapalenie błon śluzowych, } \\
\text { zwłóknienia, np. płuc, nerek, przetoki, martwica kości), odczyny popromienne ogólnoustrojowe } \\
\text { (mielosupresja, nudności, wymioty, utrata apetytu, gorączka, objawy dyspeptyczne), wtórne } \\
\text { nowotwory }\end{array}$ \\
\hline Chemioterapia & $\begin{array}{l}\text { Nudności i wymioty, krwotoczne zapalenie pęcherza moczowego, przewlekła choroba nerek, } \\
\text { ostry zespół rozpadu guza, hipomagnezemia, zmniejszenie odporności, małopłytkowość, gra- } \\
\text { nulocytopenia, zaburzenia rytmu serca, ostra niewydolność lewokomorowa serca, kardiomio- } \\
\text { patia, choroba niedokrwienna serca, polineuropatia (ototoksyczność, niedrożność porażenna } \\
\text { jelit), zapalenie błon śluzowych, biegunka, trudności w połykaniu pokarmów, włóknienie płuc, } \\
\text { ARDS, martwica tkanek po wynaczynieniu leku, utrata włosów, dermatoza, nadwrażliwość na } \\
\text { światło, niepłodność, wtórne nowotwory }\end{array}$ \\
\hline Leczenie biologiczne & $\begin{array}{l}\text { Wzrost ryzyka wystąpienia infekcji, gruźlica, niewydolność serca, nudności, wymioty, stan } \\
\text { zapalny w miejscu podania leku, suchość w ustach, biegunka, bóle stawowo-mięśniowe, re- } \\
\text { akcja autoimmunizacyjna, reakcje alergiczne, duszność, obrzęki, wysypka, gorączka, dreszcze, } \\
\text { zawroty głowy, osłabienie }\end{array}$ \\
\hline
\end{tabular}

ARDS (acute respiratory distress syndrome) — zespół ostrej niewydolności oddechowej

\section{Tabela 2. Objawy raka piersi}

\begin{tabular}{|c|c|}
\hline Objawy & \\
\hline Fizyczne & $\begin{array}{l}\text { Guz, wyciek z brodawki, powiększone węzły chłonne po stronie guza (pachowe, niekiedy szyjno-nad- } \\
\text { obojczykowe), asymetria sutków, wciągnięcie brodawki, owrzodzenie brodawki i skóry piersi, dodatkowe } \\
\text { guzki w okolicy, ból, pogrubienie skóry, obraz "skórki pomarańczy", świąd lub pieczenie brodawki, } \\
\text { miejscowe objawy zapalenia: obrzęk, ucieplenie skóry, zaczerwienienie i ból [8] }\end{array}$ \\
\hline Psychiczne & $\begin{array}{l}\text { Obniżenie samooceny, lęk, zaburzenia nastroju, epizody depresyjne, zaburzenie obrazu własnej osoby, } \\
\text { dezintegracyjne zaburzenia osobowości [9] }\end{array}$ \\
\hline Socjalne & $\begin{array}{l}\text { Pogorszenie sytuacji materialnej, problemy w pracy, obniżenie pozycji społecznej, wycofanie z kontaktów } \\
\text { społecznych, alienacja z otoczenia, poczucie braku wsparcia, lęk przed rozpadem małżeństwa i rodziny, } \\
\text { utrata więzi towarzyskich }[10,11]\end{array}$ \\
\hline
\end{tabular}

uzależniona jest od perspektywy podmiotu, który podejmuje problem. Definicja jakości życia odnosi się do obiektywnego wymiaru. Z kolei poczucie jakości życia wiąże się z ustosunkowaniem subiektywnym do rzeczywistości i jest to wymiar subiektywny [16].

\section{Ocena jakości życia}

Badania nad jakością życia pacjentów w Polsce są w dalszym ciągu nowością, jednak lekarze opisując wyniki leczenia, zwracają dużą uwagę na jego odbiór przez chorą osobę. Ocena jakości życia powinna być uzupełnieniem badania lekarskiego, w szczególności w odniesieniu do pacjentów przewlekle chorych, od których wymagane jest zaangażowanie w leczenie choroby [17].

Spośród wielu dostępnych kwestionariuszy służących do oceny jakości życia badacze najczęściej stosowany jest kwestionariusz podstawowy EORTC QLQ-C30 (The European Organization for Research and Treatment of Cancer Quality of Life Questionnaire Core 30) i moduł dla chorych z rozpoznaniem raka piersi EORTC QLQ-BR 23 (The European Organization for Research and Treatment of Cancer Quality of Life Questionnaire for Breast Cancer 23).

Kwestionariusz EORTC QLQ-C30 służy do badania subiektywnego funkcjonowania, objawów, ogólnego poczucia zdrowia i ogólnej jakości życia u chorych na 


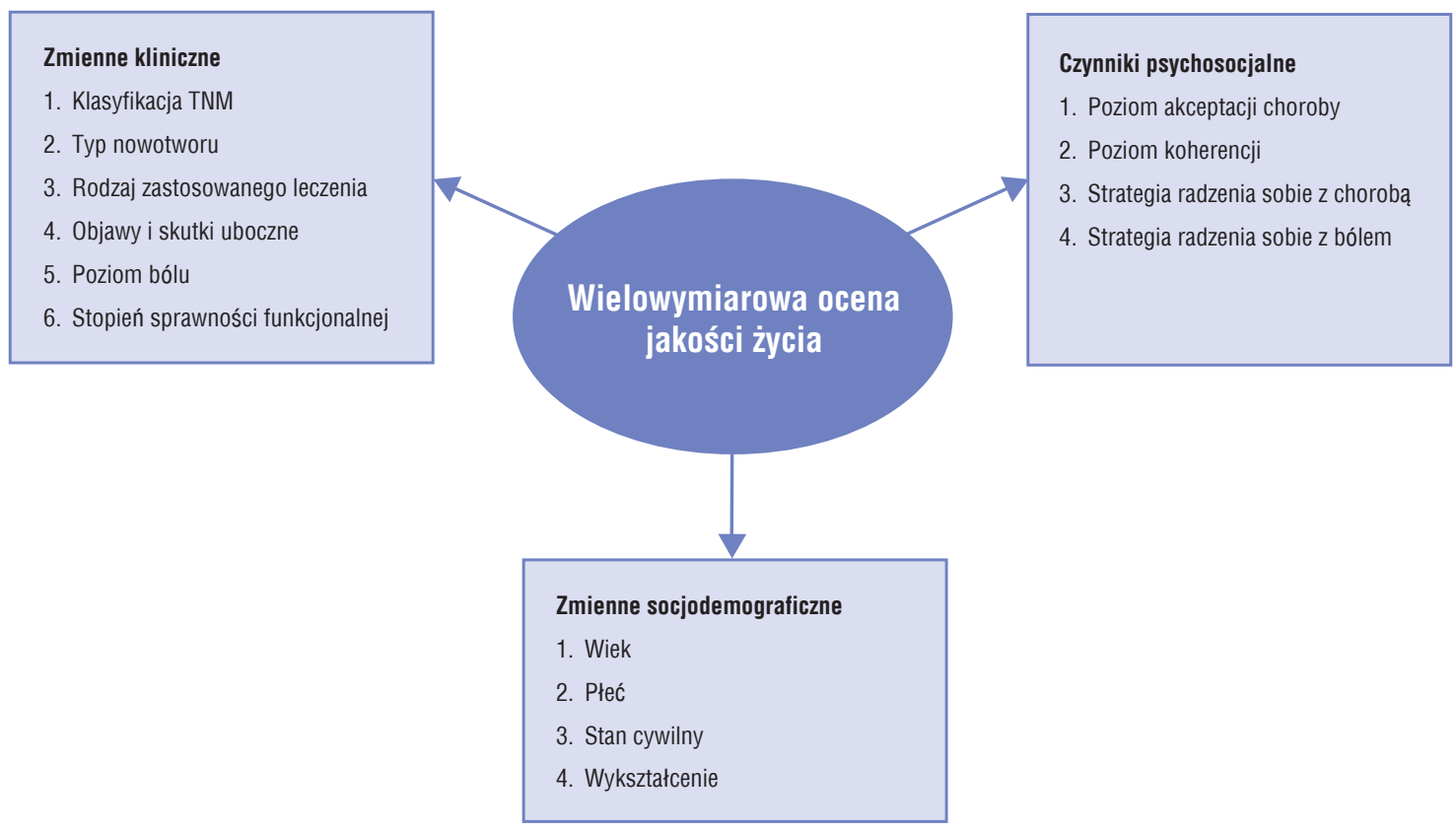

Rycina 1. Wielowymiarowa ocena jakości życia

nowotwory podczas leczenia onkologicznego. Pytania dotyczą skal funkcjonowania fizycznego, w rolach życiowych (pracy), emocjonalnego, społecznego i poznawczego. Kwestionariusz zawiera skale objawów: zmęczenia, nudności i wymiotów oraz bólu i pojedyncze pytania o duszność, bezsenność, utratę apetytu, zaparcia, biegunkę i trudności finansowe. Ostatnie dwa pytania dotyczą ogólnej oceny stanu zdrowia i ogólnej oceny jakości życia.

Kwestionariusz EORTC QLQ-BR 23 stanowi moduł przeznaczony do badania kobiet z rozpoznaniem raka piersi i zawiera skale funkcjonowania: wygląd ciała, funkcjonowanie seksualne i pojedyncze pytania dotyczące satysfakcji seksualnej i przyszłości oraz skale objawów: działania niepożądane leczenia systemowego, objawy ze strony piersi, objawy ze strony ramienia i pojedyncze pytanie o utratę włosów [18]. Moduł dla raka piersi EORTC QLQ-BR 23 powinien być wypełniany razem z kwestionariuszem podstawowym EORTC QLQ-C30.

\section{Czynniki wpływające na jakość życia}

Jakość życia kobiet z rakiem piersi jest zależna od wielu czynników, a jej poziom jest wprost proporcjonalny do stanu zdrowia. W miarę poprawy stanu zdrowia jakość życia badanych pacjentek ulega również poprawie, natomiast w przypadku pogorszenia stanu zdrowia - poziom jakości życia ulega obniżeniu. Czynniki warunkujące poziom jakości życia kobiet z rozpoznaniem raka piersi można podzielić na trzy grupy: socjodemograficzne, kliniczne i psychosocjalne (ryc. 1).

Jakość życia chorych na nowotwory piersi jest niższa, w porównaniu ze zdrową populacją [19]. Badanie przeprowadzone wśród 208 kobiet zamieszkujących obszary wiejskie Indii wykazało umiarkowaną jakość życia kobiet z rozpoznaniem raka piersi. W badaniach uwzględniono wpływ zmiennych socjodemograficznych na jakość życia. Młody wiek, brak wykształcenia i brak partnera były negatywnie związane z jakością życia, a zatrudnienie, wysoki miesięczny dochód i wyższe poczucie własnej skuteczności były pozytywnie związane z jakością życia [20]. Wykazano, że kobiety młodsze częściej poddają się negatywnym emocjom i obawiają się nawrotu choroby [21, 22]. Zaobserwowano, że kobiety z wyższym wykształceniem cechuje lepsza jakość życia [23]. Kontrowersyjny jest związek stanu cywilnego z oceną jakości życia. Kurowska i wsp. zaobserwowały, że najwyższą akceptacją choroby wykazały się panny, a najniższą — rozwódki i wdowy [24], jednak w badaniach Musiał i wsp. stan cywilny nie był istotnym determinantem jakości życia [25].

\section{Czynniki kliniczne a jakość życia}

Jednym z najważniejszych determinantów jakości życia u kobiet z rakiem piersi jest stres. Wiele kobiet doznaje silnego urazu, który powoduje przeżywanie nasilonego lęku, zwłaszcza w sytuacjach intymnych, co wiąże się z symbolicznym postrzeganiem piersi jako atrybutu kobiecości. Zachowania te są związane 
z przeświadczeniem utraty atrakcyjności fizycznej i braku możliwości wzbudzania pożądania u partnerów [26]. Po upływie roku od przeprowadzenia zabiegu operacyjnego $25 \%$ kobiet wykazuje wysoki poziom stresu, a amputacja piersi wiąże się ze zmianą obrazu własnego ciała i obrazu kobiecości, a także wpływa na funkcje seksualne i społeczne [27]. Wiele kobiet po leczeniu chirurgicznym doświadcza dolegliwości fizycznych (obrzęk chłonny, poczucie duszności) i zgłasza zmęczenie i trudności w funkcjonowaniu społecznym spowodowane brakiem akceptacji własnego ciała [28]. Młodsze kobiety odczuwają lęk o swoją przyszłość, w szczególności jako matki i odczuwają obawy związane z karmieniem dziecka [22]. Brak pozytywnej oceny postrzegania własnego ciała wpływa negatywnie na możliwości pozyskiwania środków finansowych [29]. Osoby „wyleczone” z raka piersi, zgłaszają gorsze funkcjonowanie społeczne $[30,31]$.

Wykazano związek pomiędzy nasileniem utraty apetytu, osłabienia, obrazu ciała, bólu a funkcjonowaniem seksualnym i ogólnym poziomem QoL. Najbardziej uciążliwe dla pacjentek jest zmęczenie, ból piersi, obrzęk chłonny, co powoduje złe samopoczucie psychiczne i problemy społeczne [13]. Dolegliwości bólowe ramion i klatki piersiowej występują wiele lat po „wyleczeniu”, co wiąże się między innymi ze zmianą masy ciała [32-34]. Imayama i wsp. stwierdzili związek wyższego wskaźnika masy ciała (BMI, body mass index) z bardziej nasilonymi objawami ze strony ramion i zmniejszenie dolegliwości przy spadku masy ciała o co najmniej 5\% [35]. Objawy ze strony narządu rodnego obejmują brak lub bolesne miesiączki, suchość pochwy i spadek libido [22]. Pogorszenie funkcjonowania seksualnego cechuje najczęściej chore po mastektomii [36].

Komfort psychiczny i fizyczny warunkują lepsze funkcjonowanie kobiet i wyższy poziom satysfakcji seksualnej. W analizie funkcjonowania seksualnego kobiet leczonych na nowotwory piersi, 29\% kobiet odczuwało przyjemność ze współżycia i znaczną bliskość. Z kolei kobiety dojrzałe, oceniają tę sferę neutralnie, co może wynikać z faktu, że życie seksualne wraz z wiekiem staje się mniej istotne dla kobiet, natomiast bardziej wartościowe stają się bliskość i zrozumienie ze strony partnera. Biorąc pod uwagę rodzaj zabiegu pacjentki po jednoczasowej rekonstrukcji piersi, istotnie lepiej funkcjonują seksualnie w porównaniu z kobietami leczonymi innymi metodami [36, 37].

Inne determinanty jakości życia stanowią lęk i depresja, które cechuje negatywny związek z oceną jakości życia i poziomem akceptacji choroby [38]. Ponadto, u chorych na nowotwory jakość życia zależy od cech osobowości pacjenta. Wykazano, że ekstrawertyzm u kobiet chorych na nowotwory piersi powoduje niższy poziom lęku i depresji oraz lepszą jakość życia, która jest obniżona u kobiet z neurotyzmem [39]. Poziom lęku i depresji warunkuje stan funkcjonalny kobiet z rakiem piersi. W badaniu Stępień wykazano ujemne korelacje pomiędzy poziomem lęku i depresji, a wartościami wskaźników ujmujących stan funkcjonalny w skali FACT-B (Functional Assessment of Cancer Therapy - Breast Cancer). Wraz ze wzrostem poziomu lęku i depresji następowało pogorszenie ogólnego funkcjonowania i wszystkich jego wymiarów [21]. Nasilona depresja prowadzi do wzmożonego odczuwania dolegliwości somatycznych, obniżenia motywacji do leczenia onkologicznego, braku apetytu i upośledzenia stanu odżywienia oraz zaburzeń snu, co pogarsza stan sprawności chorych. W zakresie życia rodzinnego i towarzyskiego nasilenie depresji powoduje wzrost napięcia w rodzinie, zwiększoną pobudliwość emocjonalną i pesymistyczne wizje przyszłości [40]. Nasilenie lęku objawia się wskaźnikami fizjologicznymi, takimi jak: przyspieszone tętno i oddech, wzmożone napięcie mięśni, trudności w zasypianiu lub koszmarne sny, niekiedy wzrost ciśnienia tętniczego krwi [41]. Źródło lęku u chorych na nowotwory stanowi najczęściej poczucie zagrożenia związane z utratą urody, pogorszeniem stanu zdrowia i możliwą śmiercią. Należy jednak podkreślić, że stany lękowe mogą być również spowodowane przez czynniki pozapsychologiczne, a ściśle związane z chorobą i jej leczeniem [42].

Pacjentki z rakiem piersi powinny zostać poinformowane o różnicach w jakości życia podczas omawiania możliwych metod leczenia przeciwnowotworowego [43]. Wyniki badań uwzględniających różne metody leczenia wykazały, że oprócz samej metody istotne znaczenie ma czas, jaki upłynął od pierwszego leczenia. Jest to bezpośrednio związane ze działaniami niepożądanymi terapii. Pacjentki po mastektomii, które przebyły zabieg operacyjny w okresie do 12 miesięcy, rzadziej zgłaszały objawy niepożądane, takie jak nudności i wymioty w porównaniu z chorymi, u których wykonano zabieg oszczędzający pierś ( $\mathrm{BCT}$, breast conserving therapy). Natomiast chore po zabiegu BCT były bardziej zadowolone z obrazu własnego ciała po 1-2 i 2-5 latach od przeprowadzenia leczenia operacyjnego, w porównaniu z pacjentkami po zabiegu mastektomii w tym samym okresie czasu. Nie obserwowano istotnych różnic w jakości życia po upływie 5 lat od zabiegu operacyjnego, natomiast po 15 latach jakość życia chorych na nowotwory piersi (po przebytym leczeniu operacyjnym) była porównywalna z grupą kontrolną. W okresie do 12 miesięcy od wykonania mastektomii znacznie mniej chorych zgłaszało utratę włosów, w okresie 1-2 lat lepsze 
funkcjonowanie poznawcze, natomiast po 2-5 latach większe zadowolenie seksualne [43].

Obniżenie jakości życia obserwowano u chorych poddanych adiuwantowej (stosowanej po przebytym zabiegu operacyjnym) radioterapii raka piersi. Według Chalubińskiej-Fendler i wsp. radioterapia w niewielkim stopniu wpływa na jakość życia pacjentek z rakiem piersi w porównaniu z leczeniem chirurgicznym, które znacznie zaburza różne wymiary jakości życia [44]. Najbardziej zadowolone z zabiegu operacyjnego i wyniku kosmetycznego są chore leczone metodą BCT, a najmniej pacjentki, u których wykonano mastektomię. Najwyższą jakość życia podają pacjentki po mastektomii z jednoczasową rekonstrukcją piersi $[28,36,44]$.

Biorąc pod uwagę skutki niepożądane związane z leczeniem za najbardziej uciążliwy uważany jest obrzęk kończyny górnej, który najczęściej występuje u kobiet po mastektomii, rzadziej po rekonstrukcji piersi [36]. Jankau i wsp. twierdzą, że pacjentki, u których wykonano jednoczasową rekonstrukcję w porównaniu z tymi, które miały ten zabieg odroczony, podają znaczną poprawę jakości życia, co wiąże się z brakiem konieczności stosowania protez zewnętrznych i ze zmierzeniem się ze znaczącymi i dokuczliwymi wadami ciała [45]. Czynnikiem wpływającym na istotny brak poprawy jakości życia w u chorych z zabiegami odroczonymi stanowi brak psychicznego przygotowania na skutki choroby i usunięcia piersi [46]. Po zabiegu rekonstrukcji piersi kobiety szybciej wracają do równowagi psychicznej, lepiej radzą sobie z trudną sytuacją i wykazują większą pewność siebie, co wynika z lepszego komfortu życia $[45,47]$.

Omawiając opcje leczenia, pacjentki z rakiem piersi powinny zostać poinformowane o potencjalnych różnicach w jakości życia, które wynikają z wybranej metody leczenia chirurgicznego. Pracownicy służby zdrowia powinni być świadomi zmian w poziomie QoL wśród chorych z rakiem piersi w zależności od czasu, jaki upłynął od przeprowadzenia leczenia chirurgicznego [43]. Pacjentki z chorobami towarzyszącymi, leczone cytostatykami, z niższym wsparciem społecznym i niezaspokojonymi potrzebami cechuje gorsza jakość życia. Występowanie chorób towarzyszących istotnie zwiększa częstość występowania powikłań podczas leczenia raka piersi, co może prowadzić do obniżenia jakości życia, najczęściej są to chore z rozpoznaniem cukrzycy. Jakość życia ulega poprawie wraz z upływem czasu od rozpoznania, a zachowania prozdrowotne związane są z lepszą jakością życia [48]. Jednak według Montazeri i wsp. jakość życia chorych na nowotwory piersi po upływie 18 miesięcy od rozpoczęcia leczenia pozostaje nadal obniżona w porównaniu ze stanem przed rozpoznaniem choroby [49].

\section{Psychosocjalne aspekty jakości życia}

Jakość życia kobiet z rakiem piersi zależy od czynników psychosocjalnych - akceptacji choroby, koherencji i strategii radzenia sobie z chorobą nowotworową. $\mathrm{Na}$ poczucie koherencji (SOC, sense of coherence) składa się zdolność zrozumienia wydarzeń, poczucie zaradności i sensowności podejmowanych działań i kreowania własnego życia. Poczucie koherencji jest cechą, która wpływa na sposób, w jaki ludzie radzą sobie z chorobą i na strategie, które najczęściej wybierają. Wykazano związek SOC z trzema wymiarami QoL - ogólną jakością życia, funkcjonowaniem poznawczym i społecznym. Potwierdzono także częściowy wpływ SOC na funkcjonowanie emocjonalne, zmęczenie, trudności finansowe, dobre samopoczucie i zdrowie psychiczne u kobiet przed rozpoznaniem i po 6 miesiącach [50]. Według Lindblad i wsp. osoby z wyższym poczuciem koherencji cechuje mniejsza śmiertelność z powodu raka piersi, ponadto u chorych z wyższym SOC zauważono zmniejszenie ryzyka progresji choroby. Jednak przy stwierdzeniu współistnienia objawów depresji związek SOC z umieralnością staje się nieistotny [51].

Kobiety z rakiem piersi wykazują umiarkowany poziom akceptacji choroby [38, 52]. Kozieł i wsp. potwierdzili pozytywny wpływ akceptacji choroby na ocenę jakości życia kobiet z rakiem piersi [38]. Nowicki i wsp. stwierdzili u niemal połowy badanych kobiet destrukcyjny styl radzenia sobie z chorobą [52]. W badaniu Elsheshtawy i wsp. kobiety najczęściej prezentowały sposób radzenia sobie z chorobą oparty na religii, wiele z nich pozostawiało przebieg choroby „w rękach” Pana Boga [53]. Według Ahadzadeh niepewność, jako czynnik stresogenny, powoduje obniżenie poziomu jakości życia pacjentek z rakiem piersi, a w jej poprawie pomocne są aktywne sposoby radzenia sobie z emocjami [54]. Jarkovský i wsp. stwierdzili, że negatywne strategie radzenia (rezygnacja i samooskarżenie) są związane z niższą QoL w większości domen. Rezygnacja najbardziej negatywnie wpływała na poziom QoL, natomiast aktywna konfrontacja problemowa (kontrola sytuacji i pozytywne samokształcenie) istotnie poprawiały jakość życia [54].

\section{Podsumowanie}

1. Determinanty jakości życia kobiet z rozpoznaniem raka piersi obejmują natężenie objawów choroby, lęku, depresji i stresu.

2. Metoda leczenia przeciwnowotworowego i niepożądane skutki terapii onkologicznych istotnie wpływają na poziom jakości życia kobiet z rakiem piersi. 
3. Akceptacja choroby, radzenie sobie z chorobą nowotworową i poczucie koherencji istotnie wpływają na ocenę jakości życia.

4. Pracownicy ochrony zdrowia powinni znać wpływ różnych metod leczenia i ich działań niepożądanych na poziom jakości życia pacjentek z rozpoznaniem raka piersi.

5. Ze względu na możliwość planowania procesu leczenia, a także poprawę funkcjonowania biopsychospołecznego, niezbędne jest prowadzenie badań klinicznych dotyczących czynników wpływających na jakość życia kobiet z rozpoznaniem raka piersi.

\section{Piśmiennictwo}

1. Nowotwory piersi u kobiet. http://onkologia.org.pl/nowotwory-piersi-kobiet/. (04.03.2018).

2. Jassem J, Krzakowski M. Zalecenia postępowania diagnostyczno-terapeutycznego w nowotworach złośliwych na rok 2013. Tom I. Rak piersi. http://onkologia.zalecenia. med.pl/pdf/PTOK_2013_05_Rak\%20piersi_internet2014. pdf. (14.01.2018).

3. Kozierkiewicz A. Biała Księga. Zwalczanie raka jelita grubego i raka piersi w Polsce na tle wybranych krajów europejskich. Ośrodek Analiz Uniwersyteckich, Warszawa-Kraków 2011.

4. Krzakowski M, Potemski P, Warzocha K, Wysocki P. Onkologia Kliniczna, tom 1. Via Medica, Gdańsk 2015.

5. Montazeri A. Health-related quality of life in breast cancer patients: a bibliographic review of the literature from 1974 to 2007. J Exp Clin Cancer Res. 2008; 27: 32, doi: 10.1186/1756-9966-27-32, indexed in Pubmed: 18759983.

6. Tunkel RS, Lachmann E. Obrzęk limfatyczny kończyn. Med Dypl. 1999; 8: 168.

7. Niwińska A, Maria L. Hormonoterapia uzupełniająca raka piersi. Współcz Onkol. 2007; 11: 82-88.

8. Jassem J, Krzakowski M. Rak piersi. Praktyczny przewodnik dla lekarzy. Via Medica, Gdańsk 2009.

9. Malicka I, Szczepańska J, Anioł K, et al. Zaburzenia nastroju i strategie przystosowania do choroby u kobiet leczonych operacyjnie z powodu nowotworu piersi i narządów rodnych. Współcz Onkol. 2009; 13: 41-46.

10. Mor V, Allen SM, Siegel K, et al. Determinants of need and unmet need among cancer patients residing at home. Health Serv Res. 1992; 27(3): 337-360, indexed in Pubmed: 1500290.

11. Weitzner MA. Funkcjonowanie psychospołeczne i jakość życia chorych na nowotwory gruczołu piersiowego. In: Meyza J. ed. Jakość życia w chorobie nowotworowej. Centrum Onkologii Instytutu Marii Skłodowskiej-Curie, Warszawa 1997: 225-247.

12. De Walden-Gałuszko K. Ocena jakości życia uwarunkowana stanem zdrowia. In: Meyza J. ed. Jakość życia w chorobie nowotworowej. Centrum Onkologii-Instytut im. Marii Skłodowskiej-Curie, Warszawa 1997: 77-82.

13. Sierakowska M. Krajewska-Kułak E. Jakość życia w chorobach przewlekłych- nowe spojrzenie na pacjenta i problemy zdrowotne w aspekcie subiektywnej oceny. Piel XXI W. 2004; 2: 23-26.

14. Kochman D. Jakość życia. Zdr Publ. 2007; 117: 242-248.

15. Chrobak M. Ocena jakości życia zależnej od stanu zdrowia. Probl Piel. 2009; 17: 124-127.

16. Dziurowicz-Kozłowska A. Wokół pojęcia jakości życia. Psychol Jakości Życia. 2002; 1: 77-99.
17. Chrobak M. Nie tylko wskaźniki biomedyczne. Magazyn Pielęgniarki i Położnej. 2010; 10: 1-2.

18. Zawisza K, Tobiasz-Adamczyk B, Nowak W, et al. [Validity and reliability of the quality of life questionnaire (EORTC QLQ C30) and its breast cancer module (EORTC QLQ BR23)]. Ginekol Pol. 2010; 81(4): 262-267, indexed in Pubmed: 20476597.

19. Nahleh ZA, Dwivedi A, Khang $T$ et al. Decreased Health Related Quality of Life among Hispanic Breast Cancer Survivors. Women's Health. 2016; 2(1), doi: 10.15406/mojwh.2016.02.00016.

20. Gangane N, Khairkar P, Hurtig AK, et al. Quality of Life Determinants in Breast Cancer Patients in Central Rural India. Asian Pac J Cancer Prev. 2017; 18(12): 3325-3332, doi: 10.22034/APJCP.2017.18.12.3325, indexed in Pubmed: 29286227.

21. Stępień R. Uwarunkowania społeczno-demograficzne poziomu lęku i depresji u kobiet po radykalnym leczeniu chirurgicznym raka piersi - mastektomii. Probl Piel. 2007; 15: 20-25.

22. Yfantis A, Intas $G$, Tolia $M$, et al. Health-related quality of life of young women with breast cancer. Review of the literature. J BUON. 2018; 23(1): 1-6, indexed in Pubmed: 29552751.

23. Graja T, Grodecka-Gazdecka S. Czynniki wpływające na jakość życia kobiet leczonych z powodu raka piersi. Prz Ginekol Położ. 2005; 5(3-3): 115-120, doi: 10.1066/s10014050020.

24. Kurowska K, Splerewska B. Rola przystosowania się do optymalnej jakości życia kobiet po mastektomii. Piel Chir Angiol. 2012; 3: 114-122.

25. Musiał Z, Sendecka W. Zalewska-Puchała J. Jakość życia kobiet po mastektomii. Probl Piel. 2013; 21: 38-46.

26. Chojnacka-Szawłowska G. Następstwa psychologiczne nowotworu gruczołu piersiowego i narządów rodnych. Wyd. Ossolineum. Wrocław; 1994: 31-42.

27. Milik A. Przystosowanie się do choroby u kobiet z nowotworem piersi przed mastektomia i po niej oraz przed zabiegiem oszczędzającym i po tym zabiegu. Psychoonkologia. 2013; 2: 50-55.

28. Zdończyk SA. Wpływ wybranych czynników socjomedycznych na jakość życia i funkcjonowanie psychoseksualne kobiet po leczeniu operacyjnym raka gruczołu piersiowego. Pom J Life Sci. 2015; 61: 199-206.

29. Stadnicka G., Pawłowska-Muc A., Bańkowska B. et al. Jakość życia kobiet po amputacji piersi. Technologie w optymalizacji opieki medycznej. EJMT. 2014; 4(5): 8-14.

30. Muszalik M. Kędziora-Kornatowska K. Jakość życia a stan zdrowia. Mag Piel Poł. 2007; 5: 24-25.

31. Perez DJ, Williams SM, Christensen EA, et al. A longitudinal study of health related quality of life and utility measures in patients with advanced breast cancer. Qual Life Res. 2001; 10(7): 587-593, indexed in Pubmed: 11822792.

32. Gärtner R, Jensen MB, Nielsen J, et al. Prevalence of and factors associated with persistent pain following breast cancer surgery. JAMA. 2009; 302(18): 1985-1992, doi: 10.1001/jama.2009.1568, indexed in Pubmed: 19903919.

33. Macdonald L, Bruce J, Scott NW, et al. Long-term follow-up of breast cancer survivors with post-mastectomy pain syndrome. Br J Cancer. 2005; 92(2): 225-230, doi: 10.1038/sj.bjc.6602304, indexed in Pubmed: 15655557.

34. Lee TS, Kilbreath SL, Refshauge KM, et al. Prognosis of the upper limb following surgery and radiation for breast cancer. Breast Cancer Res Treat. 2008; 110(1): 19-37, doi: 10.1007/s10549-007-9710-9, indexed in Pubmed: 17899373.

35. Imayama I, Alfano CM, Neuhouser ML, et al. Weight, inflammation, cancer-related symptoms and health related 
quality of life among breast cancer survivors. Breast Cancer Res Treat. 2013; 140(1): 159-176, doi: 10.1007/s10549013-2594-y, indexed in Pubmed: 23797178.

36. Gałka A., Świątoniowska N., Kolasińska J. et al. Assessment of the quality of life of women with breast cancer depending on the surgical treatment method used. Palliat Med Pract. 2018; 12: 76-85.

37. Poorkiani M, Abbaszadeh A, Hazrati M, et al. The effect of rehabilitation on quality of life in female breast cancer survivors in Iran. Indian J Med Paediatr Oncol. 2010; 31(4): 105-109, doi: 10.4103/0971-5851.76190, indexed in Pubmed: 21584214.

38. Kozieł P, Lomper K, Uchmanowicz B, et al. Związek akceptacji choroby oraz lęku i depresji z oceną jakości życia pacjentek z chorobą nowotworową gruczołu piersiowego. Medycyna Paliatywna w Praktyce. 2016; 10: 28-36.

39. İzci F, Sarsanov D, Erdogan Zi, et al. Impact of Personality Traits, Anxiety, Depression and Hopelessness Levels on Quality of Life in the Patients with Breast Cancer. Eur J Breast Health. 2018; 14(2): 105-111, doi: 10.5152/ejbh.2018.3724, indexed in Pubmed: 29774319.

40. Baile WF. Jakość życia i zaburzenia depresyjne u chorych na raka. In: Meyza J. ed. Jakość życia w chorobie nowotworowej. Centrum Onkologii Instytutu Marii Skłodowskiej-Curie, Warszawa 1997: 167-182.

41. De Walden-Gałuszko K. Psychospołeczne aspekty raka sutka. In: Jassem J. ed. Rak sutka. Springer PWN, Warszawa 1998: 377-391.

42. De Walden-Gałuszko K. Ból a depresja w teorii i praktyce. Psychoonkologia. 2003; 7: 25-29.

43. Tsai HY, Kuo RNC, Chung KP. Quality of life of breast cancer survivors following breast-conserving therapy versus mastectomy: a multicenter study in Taiwan. Jpn J Clin Oncol. 2017; 47(10): 909-918, doi: 10.1093/jjco/hyx099, indexed in Pubmed: 28981734.

44. Chalubinska-Fendler J, Butwicka A, Kaźmierczak P, et al. Determinants of quality of life in patients with breast cancer undergoing external beam radiotherapy. Arch Med Sci. 2015; 11(6): 1361-1362, doi: 10.5114/aoms.2015.56367, indexed in Pubmed: 26788104.

45. Potter S, Thomson HJ, Greenwood RJ, et al. Health-related quality of life assessment after breast reconstruction. $\mathrm{Br}$ J Surg. 2009; 96(6): 613-620, doi: 10.1002/bjs.6605, indexed in Pubmed: 19434704.
46. Roth RS, Lowery JC, Davis J, et al. Quality of life and affective distress in women seeking immediate versus delayed breast reconstruction after mastectomy for breast cancer. Plast Reconstr Surg. 2005; 116(4): 993-1002; discussion 1003, indexed in Pubmed: 16163084.

47. Nowicki A, Nikiel M. Operacje odtwórcze piersi, ocena satysfakcji pacjentek Współcz Onkol. 2006; 28: 264-267.

48. Goldberg P, Stolzman M, Goldberg HM. Psychological considerations in breast reconstruction. Ann Plast Surg. 1984; 13(1): 38-43, indexed in Pubmed: 6742730.

49. Montazeri A, Vahdaninia M, Harirchi I, et al. Quality of life in patients with breast cancer before and after diagnosis: an eighteen months follow-up study. BMC Cancer. 2008; 8: 330, doi: 10.1186/1471-2407-8-330, indexed in Pubmed: 19014435.

50. Rohani C, Abedi HA, Sundberg K, et al. Sense of coherence as a mediator of health-related quality of life dimensions in patients with breast cancer: a longitudinal study with prospective design. Health Qual Life Outcomes. 2015; 13: 195, doi: 10.1186/s12955-015-0392-4, indexed in Pubmed: 26651334.

51. Lindblad C, Langius-Eklöf A, Petersson LM, et al. Sense of coherence is a predictor of survival: A prospective study in women treated for breast cancer. Psychooncology. 2018; 27(6): 1615-1621, doi: 10.1002/pon.4702, indexed in Pubmed: 29528529.

52. Nowicki A, Krzemkowska E, Rhone P. Acceptance of Illness after Surgery in Patients with Breast Cancer in the Early Postoperative Period. Pol Przegl Chir. 2015; 87(11): 539-550, doi: 10.1515/pjs-2016-0001, indexed in Pubmed: 26816401.

53. Elsheshtawy EA, Abo-Elez WF, Ashour HS, et al. Coping trategies in gyptian adies with Breast Cancer. Breast Cancer: Basic Clin Res. 2014; 8: 97-102, doi: 10.4137/BCBCR. S14755, indexed in Pubmed: 24940070.

54. Ahadzadeh AS, Sharif SP. Uncertainty and Quality of Life in Women With Breast Cancer: Moderating Role of Coping Styles. Cancer Nurs. 2018 [Epub ahead of print], doi: $10.1097 /$ NCC. 0000000000000552 , indexed in Pubmed: 29489477.

55. Jarkovský J, Skřivanová K, Benešová K, et al. Predictors of quality of life in Czech female breast cancer survivors following treatment with special interest to coping strategies. Vnitr Lek. 2017; 63(6): 389-396, indexed in Pubmed: 28840734. 